\title{
REVIEW
}

UDC 591.139+604.6

doi: https://doi.org/10.15407/ubj90.03.005

\section{BIOCHEMICAL MECHANISMS OF FREE-RADICAL DAMAGE TO THE NUCLEAR GENOME BY CADMIUM}

\author{
I. M. TRAKHTENBERG ${ }^{1}$, Y. I. GUBSKY $Y^{2}$, E. L. LEVITSKY $Y^{3}$, I. F. BELENICHEV ${ }^{4}$ \\ ${ }^{1}$ Institute of Occupational Medicine, National Academy of Medical Sciences of Ukraine, Kyiv; \\ ${ }^{2}$ Insitute of Pharmacology and Toxicology, National Academy of Medical Sciences of Ukraine, Kyiv; \\ ${ }^{3}$ Palladin Institute of Biochemistry, National Academy of Sciences of Ukraine, Kyiv; \\ e-mail: levitsky@biochem.kiev.ua; \\ ${ }^{4}$ Zaporozhye State Medical University of the Ministry of Health of Ukraine
}

Cadmium, has been used for many years in industry and agriculture. Its active use is associated with a danger to human health due to a significant toxic effect on the body. The purpose of the review was to analyze the literature data and the results of our own experimental research on the biochemical mechanisms of the toxic effect of cadmium on the nuclear chromatin of cells, primarily the liver. Based on this analysis, the concept that the toxicity of cadmium is associated with damage caused by cadmium-induced free radicals was confirmed. The reactive oxygen species formed in this way are active damaging agents that cause toxic effects, including mutagenic, which ultimately leads to apoptosis and cell death.

Key wo rds: cadmium, toxicity, chromatin, DNA-damaging effect.

\section{The general toxic effects of cadmium compounds}

Heavy metals (including mercury, lead, cadmium, zinc, etc.) and their compounds are distinguished from other various pollutants by their abundance, high toxicity, and many of them - also the ability to accumulate in living organisms. They are widely used in various industrial processes, and, despite the wastewater treatment, the level of heavy metal compounds in industrial wastewater is rather high. They also enter the environment from consumer wastewater, industrial smoke and dust. Many heavy metals form stable highly soluble organic complexes that facilitate their migration into natural water sources. Heavy metals include more than 40 chemical elements; however, taking into account toxicity, stability, the ability to accumulate and distribution of toxic compounds, less number of elements (about four times) requires monitoring [1-3].

Trace amounts of some heavy metals are essential for organisms since they are important constituents of various polypeptides (including enzymes), polynucleotides and some other compounds. The intake of some heavy metals (Cd, Zn, Hg, Cu, $\mathrm{Au}$ ) into the body is accompanied by intensive synthesis of particular proteins - metallothioneins, multifunctional proteins involved in transmembrane transport and protection from heavy metal toxicity. It is known that the metabolism of minerals occurs under genetic control. Thus, mutations affecting the transport of magnesium, iron, cobalt, chromium, selenium, molybdenum and cadmium were found in experimental animals [4-6].

The aim of this paper is to review the findings that reveal the DNA-damaging effect of cadmium, the most typical representative of heavy metals, which is widely used in the industry and manufactures, and thus, contributes to environmental pollution. There is a large amount of published data about cadmium indicating that its toxic effect underlies free radical mechanism. The results of experiments on nuclear liver chromatin of animals intoxicated

(C) 2018 Trakhtenberg I. M. et al. This is an open-access article distributed under the terms of the Creative Commons Attribution License, which permits unrestricted use, distribution, and reproduction in any medium, provided the original author and source are credited. 
with cadmium chloride are presented as a proof of this theory, where the authors postulated for the first time a free radical mechanism of cadmium DNA damaging effect. Numerous recently reported data, that reliably support this hypothesis, are also presented in this article.

Cadmium, a variable valence metal, has been used in the industry and agriculture for many years. Its main uses in industry today are related to five areas: the production of nickel-cadmium batteries; pigments for plastics, ceramics and glass; PVC heat and light stabilizers; electroplated cadmium coatings; and as a component in the specialized alloys [7-11]. Cadmium is mainly used in the development of pigments and chemically pure toners (coloring powders), but also for the conversion of solar energy into electrical energy. Cadmium carbonate and cadmium chloride are used to produce cadmium sulfide, which possesses photoconductive and electroluminescent properties, for use in the production of special mirrors, pigments for special paints, textiles, paper, rubber, plastics and fireworks, and as fungicides [12-14]. By 1987, the cadmium's use level in each of indicated industrial sector was estimated to be $30 \%$ of total US cadmium consumption [15].

Intensive use of cadmium in industry, agriculture and everyday life has led to environmental pollution [16]. Therefore, the study of the toxic effect of heavy metals, in particular cadmium, and the consequences of this effect on living organisms, is urgently required. Cadmium and its salts are characterized by polyvalent toxic effects, depending on the mode of exposure and the penetration into the body of animals and humans. The reported data have described a variety of toxic effects of cadmium on the kidneys, nervous, cardiovascular systems, lungs, blood and the gastrointestinal tract. There are also data on its carcinogenic and teratogenic effects [17-20]. In humans and laboratory animals, acute and chronic inhalation or oral exposure to cadmium causes damage to the proximal tubules of cell membranes inducing reabsorption of phosphates, glucose, amino acids, and low molecular weight proteinuria, involving, especially, $\beta 2$-microglobulin and certain enzymes [2124]. The studies on the effect of cadmium ions on liver cells of different species of animals and humans showed that cadmium exposure induced nonspecific reactions in the liver indicating its hepatotoxicity. Thus, an increase in serum gamma globulin, a positive Takata reaction, increased thymol levels were observed in workers exposed to cadmium salts [25-
27]. In rats, cadmium inhalation exposure at a concentration of $0.1 \mathrm{mg} / \mathrm{m}^{3}$ for 30 days led to an increase in ALT activity that indicates liver damage [28].

In experimental animals, cadmium intoxication led to an increase in the liver weight [29, 30], a decrease in glycogen stores and an increase in blood glucose concentration [16]. The discovered nonspecific histopathological indicators, such as intralobular fibrosis, cirrhosis, the presence of focal mononuclear infiltrates, as well as the proliferation of smooth endoplasmic reticulum, are contributed evidence of cadmium hepatotoxicity. In addition, what is important in this case, drastic changes in the lipid composition and lipid peroxidation reactions (LPO) in liver cells were observed [31,32]. One of the suggested mechanisms of cadmium cardiotoxicity is a decrease in the activity of antioxidant enzymes, in particular, glutathione peroxidase and superoxide dismutase [33]. Cadmium was shown to be able to change the metabolism of zinc, iron and copper ions, which are important cofactors of antioxidant enzymes; as well as other biologically active substances (BAS), and selenium. The authors in [34] suggested that the initial stage of cadmium-induced toxicity is its interference with zinc-protein complexes involved in DNA transcription that subsequently stimulates apoptosis (see below). Following exposure to metallothionein (or exposure to synthetic chelator [34]) prevented disruption in zinc-dependent control of transcription caused by cadmium intoxication.

Based on these data, it can be assumed that cadmium (especially its chloride) is one of the most hazardous representatives of heavy metals, whose toxic effects have been confirmed in numerous studies. However, subtle biochemical mechanisms for cadmium toxic action, in particular, its DNAdamaging effect, are remained poorly understood.

In earlier study we were among the first who proposed an experimentally confirmed hypothesis of cadmium DNA-damaging effect [35], in which a central role is played by cadmium-induced reactive oxygen species, which induce the LPO modification causing damage to important biomolecules leading to hepatocytes damage, in the first place, the dysfunction of nuclear chromatin.

According to this concept, toxic damage to the cell initially affects the cell membranes, primarily the endoplasmic reticulum, inducing the generation of reactive oxygen species (ROS) which cause oxidative DNA and protein damage, and, as a result, apoptotic cell death [36]. 
The role of mitochondria in cadmium-mediated nephrotoxicity was studied in [37]. Normally, there is a balance between ROS formation and the antioxidant enzymes activity. However, upon cadmiuminduced mitochondrial dysfunction, mitochondria begin producing less energy and more ROS. The imbalance between levels of ROS and antioxidant enzymes lead to oxidative stress and following multiple negative multifactor's consequences: the loss of mitochondria membrane potential causes activation of apoptosis via cytochrome C- and caspase-dependent pathways. These mechanisms for mitochondrial regulation disorders (upstream signaling pathways, direct mitochondrial targeting, and downstream cell death effector pathways) are the argument for the use of antioxidants in case of cadmium-induced nephrotoxicity.

Such involvement of free-radical reactions, aroused in membranes of the endoplasmic reticulum in response to stress, has been recently reported in a number of recent works [38].

\section{Free-radical chromatin- and DNA- damaging effects of cadmium ions}

Initially, the damage to chromatin and its constituent DNA results from the cadmium-induced endoplasmic reticulum stress [39]. In this work, the authors showed that the endoplasmic reticulum stress plays a key role in the cadmium-induced DNA-damaging activity. As a result, induction of apoptosis in target tissues (primarily in the liver and kidneys, see below) occurs. In the latter case, abnormal unfolded protein response is involved in the toxic process. Such abnormal response is also induced by ROS.

In addition to ROS in membranes of the endoplasmic reticulum, free radicals are also formed as a result of LPO free radical reactions in chromatin fractions [40-42]. Previously, we postulated that the balance in LPO free radical reactions in nuclear chromatin is an important mechanism for regulating its activity [40]. Oxidative damage to components of the nuclear genome - DNA, proteins and lipids leads to the abnormality in the main biochemical reactions in chromatin: replication, repair, transcription.

In previous work, we studied in detail mechanism of the cadmium chloride toxic effect on subcellular components of liver cells [35]. The relationship between the chromatin state (functional and structural) and the cadmium chloride-activated LPO re- actions in the repressed chromatin (RC) and transcriptionally active chromatin (TAC) of liver cells was found.

In this paper, we proposed an experimentally supported hypothesis for the mechanisms of DNA damaging effect of cadmium ions, in which ROS have a key role to play. ROS are involved in a modification of LPO reactions that lead to disorder in structure and function of vital biomolecules resulting in damage to hepatocytes, in the first place to the functioning of their nuclear genome.

It was shown on animal experiments that administration of cadmium chloride, at a dose of $5 \mathrm{mg} /$ $\mathrm{kg}$ body weight $24 \mathrm{~h}$ before decapitation altered RC and TAC levels significantly, and the level of the latter decreased. However, the protein/DNA ratio in TAC fraction increased, that may be a consequence of the increase in protein level in this fraction. We suggested that such a structural modification may be caused by a change in the intensity of the LPO reactions. Indeed, cadmium chloride intoxication led to activation of NADPH-dependent LPO-reactions in the TAC fraction. Other parameters of spontaneous (evaluated by diene conjugate level) and induced LPO were not significantly changed (Table 1). In the RC fraction, on the contrary, intoxication led to a decrease in NADPH-induced and spontaneous LPO. In this case, the different effect of cadmium chloride on the LPO-reactions in chromatin fractions may be account for differences in their structure and in fatty acid compositions of lipids [43, 44]. The cadmium chloride exposure altered, to some extent, the functional activity of the fractionated liver chromatin. In $\mathrm{RC}$, the enzymatic activity of the fraction enriched in RNA polymerase I decreased significantly. In the TAC fraction, the toxicant exposure led to a decrease in total DNA polymerase activity due to a decrease in the activity of replicative DNA polymerase $\alpha$ (Table 2).

A decrease in the intensity of DNA synthesis during cadmium chloride intoxication was also observed by other authors [45]. Earlier, we established an inverse relationship between the DNA synthesis and the intensity of LPO reactions in the RC and TAC fractions [46]. In this case, cadmium chloride intoxication is assumed to induce free-radical LPO reactions in RC and TAC that results in abnormal DNA synthesis due to defects in structural-functional replication complex. Cadmium chloride intoxication also intensified oxidative modification of rat blood plasma proteins (Table 3). 
Ta b le 1. Intensity of LPO-reactions in rat liver cells chromatin fractions during cadmium chloride intoxication

\begin{tabular}{|c|c|c|c|c|}
\hline \multirow[t]{2}{*}{ Parameters } & \multicolumn{2}{|c|}{ Repressed chromatin } & \multicolumn{2}{|c|}{$\begin{array}{l}\text { Transcriptionally } \\
\text { active chromatin }\end{array}$} \\
\hline & Control & Experiment, $24 \mathrm{~h}$ & Control & Experiment, $24 \mathrm{~h}$ \\
\hline \multicolumn{5}{|c|}{ Diene conjugates content (nmol/mg of protein) } \\
\hline Heptanoic extract (neutral lipids) & 73.3 & $12.1^{*}$ & 19.1 & 18.7 \\
\hline Isopropanolic extract (phospholipids) & 391.7 & $525.5^{*}$ & 290.1 & $316.8^{*}$ \\
\hline \multicolumn{5}{|c|}{ Malone dialdehyde accumulation (nmol/mg of protein during $2 \mathrm{~h}$ ) } \\
\hline NADPH-dependent LPO & 992.6 & 1004.2 & 372.4 & $527.6^{*}$ \\
\hline $\begin{array}{l}\text { Enzymic component of } \\
\text { NADPH-dependent LPO }\end{array}$ & 149.7 & 147.1 & 50.0 & $102.3^{*}$ \\
\hline Ascorbate -dependent LPO & 436.8 & 330.0 & 1288.2 & 1652.8 \\
\hline Nonititiated control & 133.1 & 115.6 & 25.0 & 25.7 \\
\hline
\end{tabular}

Table 2. Intensity of endogenous DNA- and RNA-synthesis in rat liver cells chromatin fractions during acute cadmium chloride intoxication

\begin{tabular}{l|c|c|c|c}
\hline \multirow{2}{*}{ Parameters } & \multicolumn{2}{c|}{ Repressed chromatin } & \multicolumn{2}{c}{$\begin{array}{c}\text { Transcriptionally } \\
\text { active chromatin }\end{array}$} \\
\cline { 2 - 4 } & Control & Experiment, 24 h & Control & Experiment, 24 h \\
\hline \multicolumn{2}{c}{ Enzymes' activity of DNA- and RNA-synthesis $($ dpm/mg DNA) } \\
Total DNA-polymerase activity & 851600 & 1179628 & 227514 & $82253^{*}$ \\
Activity of DNA polymerase $\alpha$ & 785440 & 1077097 & 206686 & $65996^{*}$ \\
Activity of DNA polymerase $\beta$ & 66160 & 102530 & 20828 & 16257 \\
Total RNA-polymerase activity & 62477 & 62845 & 402978 & 488543 \\
Activity of RNA polymerase I & 37864 & $15991^{*}$ & 224745 & 274237 \\
Activity of RNA polymerase II & 24613 & 46854 & 178233 & 214305 \\
\hline
\end{tabular}

Note: $n=5$; * $P<0.05$ with compare to control.

Ta ble 3. Parameters of oxidative modification of rat blood plasma proteins during chronic cadmium chloride intoxication $(M \pm m, n=7)$

\begin{tabular}{l|c|c|c|c|c|c}
\hline \multirow{2}{*}{ Parameters } & \multirow{2}{*}{ Control } & \multicolumn{5}{|c}{ Experiment (days) } \\
\cline { 3 - 7 } & & 1 & 7 & 14 & 21 & 28 \\
\hline $\mathrm{OPM}_{370}$ & $1.31 \pm 0.01$ & $2.72 \pm 0.07^{*}$ & $2.72 \pm 0.02^{*}$ & $2.77 \pm 0.05^{*}$ & $1.98 \pm 0.03$ & $2.32 \pm 0.06^{*}$ \\
$\mathrm{OPM}_{430}$ & $0.49 \pm 0.01$ & $0.90 \pm 0.04^{*}$ & $0.87 \pm 0.10^{*}$ & $0.92 \pm 0.04^{*}$ & $0.64 \pm 0.01^{*}$ & $0.78 \pm 0.02^{*}$ \\
\hline
\end{tabular}

Note: $n=5 ;{ }^{*} P<0.05$ with compare to control.

Thus, administration of a water solution of cadmium chloride to animals was shown to lead to the changes in the biochemical parameters related to the structure and functional activity of rat liver chromatin fractions characterized by different transcriptional activities. The change in the intensity of free- 
radical LPO reactions in chromatin was assumed to underlie the DNA damaging effect of cadmium chloride on liver cells.

This assumption was further corroborated by works of other researchers. Thus, the authors in [47] evaluated the cadmium toxic effects on chick embryo liver tissue. Cadmium at a dose of 40, 50 and $60 \mu \mathrm{g}$ at intervals of 24,48 and $72 \mathrm{~h}$ was administered in ovo on the $10^{\text {th }}, 11^{\text {th }}$ and $12^{\text {th }}$ days of the development of Babcock strain chicken embryos. On the $13^{\text {th }}$ day of the experiment, blood and liver tissue were collected and tested for DNA-damaging activity and intensity of LPO reactions. The occurrence of micronucleus in erythrocytes and the number of abnormal blood cells were also assessed. These parameters increased with an increase in cadmium concentration and time of exposure. The level of malonic dialdehyde (MDA) also increased in the cadmium-exposed groups compared to control. The authors concluded that the free-radical mechanism is involved in the DNA-damaging effect of cadmium.

The DNA damaging effect of cadmium on Nile tilapia fish was studied using cytogenetic and molecular biological methods (micronucleus formation and comet assay) [48]. It was found that an increase in cadmium dose and exposure time led to the increase in the number of damaged nuclei and the formation of DNA comets.

The authors believe that the cadmium DNA damage is caused by the increase in the ROS formation, i.e., due to free radical mechanisms.

Similar results were reported in [49]. The authors investigated the DNA damaging effect of cadmium chloride on the marine gastropod Nerita chamaeleon using comet assay and DNA alkaline unwinding assay (DAUA). The detected DNA damage was similar to that induced by hydrogen peroxide in vitro. Based on these findings, the authors postulated that DNA damage by cadmium chloride occurs via the free radical mechanism.

In the study [50], molecular mechanisms for cadmium damaging effect on DNA in cultured human cells A549 and VH10hTert were investigated. The authors proposed a scheme for the molecular mechanism of the DNA-damaging effect of cadmium compounds (cadmium oxide and cadmium chloride):

The authors believed that cadmium-induced oxidative DNA damage underlies cadmium genotoxicity since the direct interaction of cadmium ions with the components of the nuclear genome is unlikely pathway of action. It was shown that the

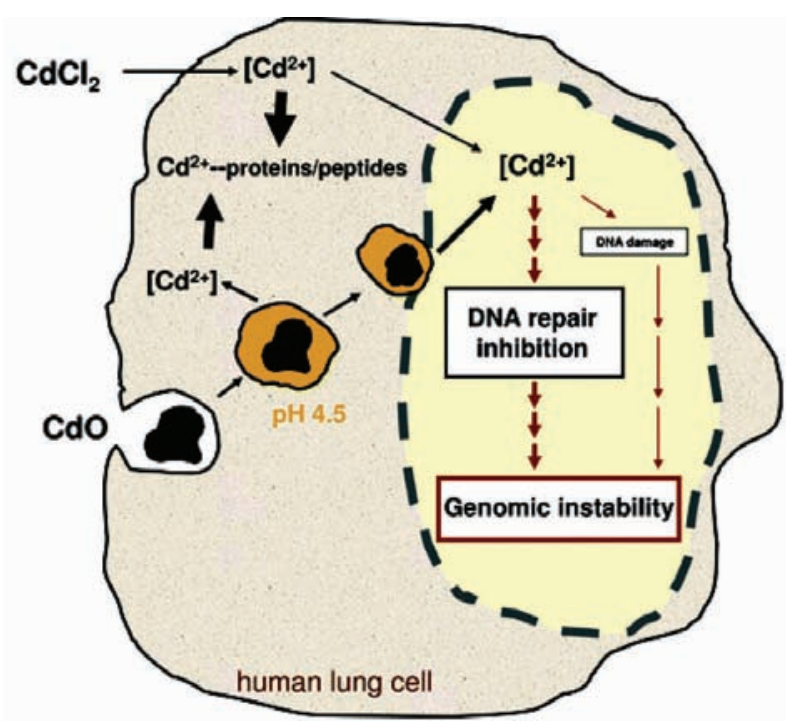

Fig. 1. A scheme postulating the molecular mechanism for oxidative damage to human lung cells by cadmium compounds [50]

uptake of cadmium led to inhibition of DNA adduct repair, similar in nature to oxidative DNA damage in cadmium-induced carcinogenesis. It was also shown that the mechanism of damage, in this case, is connected with the change in the conformation of the zinc-binding domain of the tumor suppressor p53 by cadmium.

In a recently published paper [51], the authors investigated cadmium-induced DNA damage and cytotoxicity in peripheral blood erythrocytes of Labeo rohita fish exposed to cadmium chloride at a concentration of 0.37 and $0.62 \mathrm{mg} / \mathrm{l}$ in water for 100 days. The blood samples were collected at different time intervals $(1,3,5,10,15,30,60$ and 100 days) and analyzed for DNA damage using comet assay, determining the number of micronuclei and other cellular abnormalities [52]. The results of comet assay showed that mean values (\%) of tail DNA increased significantly at both concentrations. Cadmium also induced several other nuclear abnormalities such as binucleation, bud-shaped, lobed, notched and vacuolated nuclei. Cytoplasmic abnormalities such as echinocytes, acanthocytes, microcytes and cells with notched and vacuolated cytoplasm were also detected. All the studied parameters were found to be increased in a concentration-dependent manner with a peak on the $10^{\text {th }}$ day in the cadmium-exposed group compared to control and decreased after the $15^{\text {th }}$ day of exposure.

Thus, cadmium ions were established to be able to induce the generation of reactive oxygen species 
in the mitochondria and other cell compartments. A reduction in the activity of antioxidant enzymes or an increase in the formation of reactive oxygen species causes serious damage to the structure of proteins, lipids and chromatin DNA [34].

The assumption that cadmium toxic effect occurs via free radical mechanism is evidenced by its pronounced carcinogenic activity (the connection between these two activities is well established [36], see for example [53]).The authors indicated that cadmium causes damages, typical to the carcinogen, including ROS induction and inhibition of DNA repair. In this work, the evidence of cadmium mutagenic effect was given. It was suggested that cadmium compounds induce mutations through free radical mechanism resulting in genetic instability. Inhibition of repair leads to exo- and endogenous DNA damage, which, in turn, causes an increase in the probability of mutations and initiation of carcinogenesis.

\section{Apoptotic mechanisms of free-radical toxic effect of cadmium ions}

Such cell damage leads to cell death and apoptosis [54]. It was shown that the mitogen-activated protein kinases (MAPKs) signaling system is involved in inducing apoptosis by increasing the ROS level. Exposure to cadmium leads to a significant increase in the ROS production by inhibiting the glutathione antioxidant system and binding the protein sulfhydryl groups [36].

In this monograph, we analyzed thoroughly general mechanisms for free radical toxic damage to the liver, leading, ultimately, to necrotic-apoptotic cell death. Earlier a detailed analysis of cadmiuminduced toxic free radical damage to the liver cells, which leads via apoptosis to damage and cell death, was carried out by Arroyo V.S., Flores K.M., et al [55]. Fig. 2 (taken from their report) illustrates proposed metabolic pathway of cell damage caused by cadmium-induced free radical damage.

It should be noted that the idea suggested in this paper about the role of calcium ions and cytochrome C450 in a toxic process that leads to apoptotic organ damage is consistent with our view represented in the above-mentioned monograph [36].

In a later report [56], cadmium chloride was shown to induce apoptosis in various types of cells, including osteoblasts, both in vitro and in vivo. However, until recently, the mechanisms of this process have remained unclear. The authors used the MG63 human osteosarcoma cell line, similar in characteristics to human osteoblasts. It was established that a short-term exposure to cadmium chloride induces apoptosis in these cells. In addition, the content of phosphorylated proteins p38MAPK significantly increased and the content of ERK1/2 decreased in a concentration-dependent manner. Inhibition of p38MAPK phosphorylation by SB202190 protects the cells from Ca-induced apoptosis. The cell incubation with PD98059 - an ERK1/2 inhibitor - had the same effect. Acetylcysteine significantly reduced the ROS level and exerted an effect opposite to that of cadmium on MAPK-dependent signaling systems. The authors concluded that cadmium induces cell apoptosis by increasing the ROS formation, activating the p38MAPK-related signaling system and inhibiting the ERK1/2-dependent one.

The mechanisms of the toxic effect of cadmium compounds were analyzed thoroughly in a review [57]. Cadmium was emphasized to cause diverse

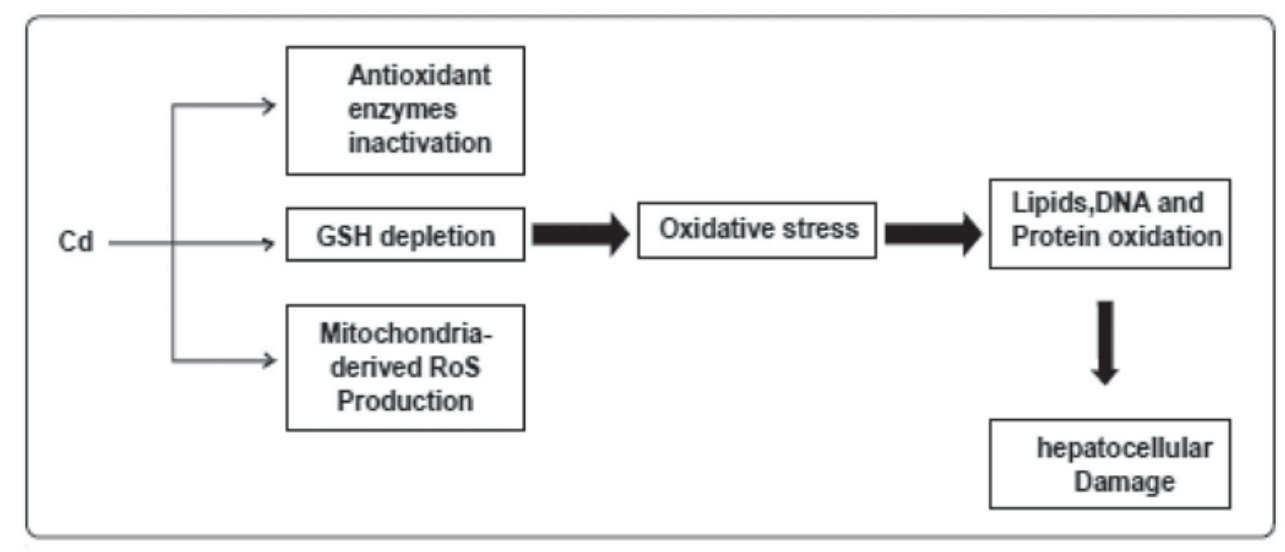

Fig. 2. Cadmium-induced oxidative stress: specific metabolic pathways of cellular damage caused by free radical damage by this toxicant are proposed [55] 
toxicity, including hepatotoxicity, nephrotoxicity, teratogenicity, reproductive and endocrine toxicity. At the cellular level, cadmium intoxication leads to apoptosis. The toxic effect of cadmium is realized via genome instability caused by disruption to DNA repair, the formation of reactive oxygen species and the induction of apoptosis. These findings agree well with statements reported in our monograph [36].

Molecular mechanisms underlying DNA damaging effects of cadmium compounds were discussed in detail in [58]. It was postulated that cadmium initially induces, through the stress of the endoplasmic reticulum, generation of reactive oxygen species, including hydroxyl radicals which have a pronounced DNA-damaging effect [42]. Further, this mechanism is realized through inhibition of DNA repair and induction of apoptosis, eventually, resulting in carcinogenesis and cell death [36].

Molecular mechanisms responsible for disruption of DNA repair in human bronchial epithelium cells $16 \mathrm{HBE}$ under the influence of cadmium intoxication were analyzed in [59]. It was indicated that cadmium is a known toxic carcinogen, which exerts a malignant effect by disruption to DNA repair processes. The authors assessed gene expression and DNA methylation in control cells and in cells exposed to cadmium chloride. For these purposes, they applied HPLC, real-time PCR, Western blot analysis, and methylation-specific PCR assay. It was found that during Cd-intoxication, the total DNA methylation progressively increased, which was associated with the overexpression of the methyltransferase genes DNMT1 and DNMT3a but not DNMT3b. Expression of both the messenger RNA and proteins of the DNA repair genes ( $h M S H 2, E R C C 1, X R C C 1$, and hOGG1) progressively decreased and along with Cdinduced transformation the degree of DNA damage increased. The promoter sites of hMSH2, ERCC1, $X R C C 1$, and $h O G G 1$ genes were hypermethylated. The DNA demethylating agent 5-aza-2'-deoxycytidine has the ability to reverse the cadmium-induced DNA hypermethylation, DNMT hyperactivity and silencing of hMSH2, ERCC1, XRCC1, and hOGG1 genes in a time-dependent manner. These results indicate that DNMT1 and DNMT3a overexpression can cause global DNA hypermethylation and the silencing of hMSH2, ERCC1, XRCC1 and hOGG1 genes. These data can partly explain the epigenetic mechanisms of cadmium-induced carcinogenesis.

Biochemical mechanisms of cellular cadmium toxicity resulting in apoptosis and cell death were described in an earlier work [60]. It was outlined that cadmium induces significant DNA damage in embryonic cells and also induces embryonic growth retardation due to upregulation of p53, p21 protein transcription, downregulation of $\mathrm{Bcl}-2$ protein and shifting the Bcl-2/Bax equilibrium towards apoptosis, as well as an increase in the procaspase-3 activity. These effects are likely to occur via zinc-related mechanisms since the zinc pretreatment ameliorates toxic effects of cadmium.

The critical role of oxidative stress in DNA damage and apoptosis of liver carcinoma cells upon cadmium chloride intoxication was demonstrated clearly in [61]. The authors showed that under these conditions, oxidative stress plays a key role in activation of LPO reactions (a significant increase in hydroperoxide production was registered), DNA damage (analyzed by alkaline single cell gel electrophoresis Comet assay). These processes led, eventually, to a programmed cell death - apoptosis of HepG2 carcinoma cells.

The recent report [62] indicated that cadmium, depending on the concentration and cell type, may disrupt cellular homeostasis via complex mechanisms involving interaction with other metals, induction of oxidative stress and apoptotic or necrotic cell death. The authors proved that cadmium chloride causes DNA damage in Jurkat T cells (significantly, relative to control), and also leads to a decrease in the activities of superoxide dismutase and glutathione peroxidase, an increase in LPO and carbonyl protein level. At the same time, the levels of glutathione and total sulfhydryl groups were significantly reduced indicating that cadmium induces oxidative stress. These results, according to the authors, prove that cadmium causes disruption of cellular redox homeostasis, which, in turn, leads to lipid and protein oxidation, as well as to oxidative DNA damage in Jurkat T cells.

The free radical mechanism of cadmium-induced chromatin- and DNA-damage was confirmed by the pronounced protective effect of antioxidants during cadmium intoxication. Thus, in recent work [63], authors studied the protective effect of medicinal plant Moringa oleifera on the liver, kidneys, testes, lipid profile and hematological parameters of adult Wistar rats upon cadmium-induced damage to these organs. Pretreatment with the antioxidant obtained from this plant was found to have a protective effect.

The protective role of antioxidants was also shown in other studies. Thus, Błasiak [64] demonstrated by means of alkaline comet assay that anti- 
oxidant quercetin plays a protective role in cadmium chloride lymphocytes damage. The cells exposed to cadmium chloride $(5-150 \mu \mathrm{M})$ were shown to restore their functions at the pretreatment them with quercetin at a dose of $50 \mu \mathrm{M}$. The author believes that quercetin can chelate cadmium ions, scavenge free radicals, or regenerate DNA repair enzymes.

Cadmium was indicated to be a mutagenic and carcinogenic metal [65]. Cadmium-induced oxidative stress leads to the cytotoxic effects. Nuclearfactor-erythroid 2-related factor 2 (Nrf2), the main member of the leucine-zipper (bZip) family of transcription factors, was found to exhibit a protective action during cadmium-induced oxidative stress and DNA-damage.

Thus, the stages of toxic effects of cadmium compounds can be represented by diagram:

\section{Free radical generation}

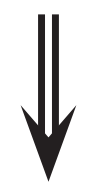

2. Free-radical damage to DNA and chromatin<smiles>C=CC</smiles>

3. Apoptosis

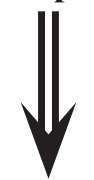

via these pathways

\section{Overall toxic effect of cadmium compounds}

is realized leading to permanent damage to organs and tissues

Similar views were presented in the last two cited review papers $[66,67]$. In the first work, authors considered mechanisms of oxidative DNA damage and its effect on cellular metabolism. Oxi- dative DNA damage was stated to be an irreversible consequence of toxic damage to the cell. More than 20 anomalous DNA bases were detected; 8-hydroxy21-deoxyguanosine is the most studied among them. Its appearance leads to a modification of the activity of DNA repair enzymes. Defective repair, in turn, results in the development of a number of pathological processes, in particular, carcinogenesis. Such damage to DNA was suggested to use as a biomarker for the detection of pathologies associated with the intoxication, e.g. with cadmium.

The consequences of intoxication with cadmium compounds were reported in detail in [67]. It was emphasized that cadmium is an important heavy metal environmental pollutant. Important sources of human intoxication with cadmium are the industry and manufacture that use it as one of the main raw materials, as well as cigarette smoke, food, water and air pollution. The toxic effect occurring via the above-described molecular events may result in humans in cancers of the prostate, lungs and testes. It is these organs are damaged upon acute intoxication. Chronic intoxication is accompanied by obstructive airways disease, emphysema, irreversible renal failure, metabolic bone disorders and immunosuppression. At the cellular level, cadmium affects proliferation and differentiation leading to apoptosis. All this occurs due to indirect induction by cadmium of ROS generation (see above) followed by DNA damage. Thus cadmium modulates gene expression and signal transduction, reduces the activity of antioxidant enzymes that lead to impaired DNA repair processes.

The authors highlighted the role of cadmiuminduced damage to DNA, membranes and proteins, the inhibition of various types of DNA repair, and apoptosis in these disorders. Such results are consistent with the proposed by us molecular mechanisms of cadmium-induced free radical damage to the nuclear genome and effects of this damage on cell and organism (see diagram). 


\section{БІОХІМІЧНІ МЕХАНІЗМИ ВІЛЬНО- РАДИКАЛЬНОГО УШКОДЖЕННЯ ЯДЕРНОГО ГЕНОМУ КАДМІЕМ}

\author{
I. М. Трахтенберг ${ }^{1}$ Ю. І. Губськийㄹ, \\ Є. Л. Левицький ${ }^{3}$, I. Ф. Бєленічев ${ }^{4}$
}

${ }^{1}$ Інститут медицини праці НАМН України, Київ; ${ }^{2}$ Інститут фармакології і токсикології НАМН України, Київ;

${ }^{3}$ Інститут біохімії ім. О. В. Палладіна НАН України, Київ;

e-mail: levitsky@biochem.kiev.ua;

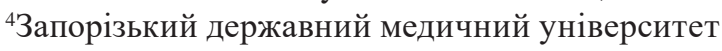

Міністерства охорони здоров'я України

Кадмій протягом багатьох років використовується в промисловості і сільському господарстві. Активне його застосування пов'язано 3 небезпекою для здоров'я людини, зважаючи на значний рівень токсичної дії на організм. Мета огляду - проаналізувати дані літератури і результати власних експериментальних досліджень, що стосуються біохімічних механізмів токсичної дії кадмію на ядерний хроматин клітин, передусім, печінки. На підставі цього аналізу підтверджено концепцію, згідно 3 якою токсичність кадмію визначається ушкодженнями, спричиненими вільними радикалами, виникнення яких індукують іони токсиканту. Утворені при цьому реактивні види кисню $€$, самі по собі, активними ушкоджуючими агентами, що зумовлюють токсичні ефекти, в тому числі мутагенний, що призводить у кінцевому підсумку до апоптозу і загибелі клітини.

К л ю ч о в і с л о в а: кадмій, токсичність, хроматин, ушкодження ДНК.

\section{БИОХИМИЧЕСКИЕ МЕХАНИЗМЫ \\ СВОБОДНОРАДИКАЛЬНОГО \\ ПОВРЕЖДЕНИЯ ЯДЕРНОГО \\ ГЕНОМА КАДМИЕМ}

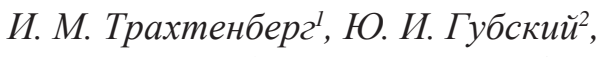
Е. Л. Левиикийㄱ, И. Ф. Беленичев ${ }^{4}$

${ }^{1}$ Институт медицины труда НАМН Украины, Киев; ${ }^{2}$ Институт фармакологии и токсикологии

НАМН Украины, Киев;

${ }^{3}$ Институт биохимии им. А. В. Палладина НАН Украины, Киев;

e-mail: levitsky@biochem.kiev.ua;

4Запорожский государственный

медицинский университет Министерства здравоохранения Украины

Кадмий на протяжении многих лет используется в промышленности и сельском хозяйстве. Активное его применение связано с опасностью для здоровья человека ввиду значительного токсического действия на организм. Цель обзора - проанализировать данные литературы и результаты собственных экспериментальных исследований, касающихся биохимических механизмов токсического действия кадмия на ядерный хроматин клеток, прежде всего, печени. На основании этого анализа подтверждена концепция, согласно которой токсичность кадмия определяется повреждениями, вызванными свободными радикалами, возникновение которых индуцируют ионы токсиканта. Образующиеся при этом реактивные виды кислорода являются, сами по себе, активными повреждающими агентами, вызывающими токсические эффекты, в том числе мутагенный, что приводит в конечном итоге к апоптозу и гибели клетки.

К л ю ч е в ы е слов а: кадмий, токсичность, хроматин, повреждение ДНК. 


\section{References}

1. Trakhtenberg IM. A book about poisons and poisonings. Essays on toxicology. Kiev: Naukova Dumka, 2000. 368 p.

2. Trakhtenberg IM, Levitsky EL. Prophylactic toxicology in Ukraine: time link in solving current problems. Environ Health. 2006; 39(4): 3-8.

3. Trakhtenberg IM, Levitsky EL. Genetic toxicology. In: Genetic Medicine. Publ.: Odessa Med. Univ., 2008: 183-221.

4. Elinder CG. Cadmium as an environmental hazard. IARC Sci Publ. 1992; (118): 123-132.

5. Hengstler JG, Bolm-Audorff U, Faldum A, Janssen K, Reifenrath M, Götte W, Jung D, Mayer-Popken O, Fuchs J, Gebhard S, Bienfait HG, Schlink K, Dietrich C, Faust D, Epe B, Oesch F. Occupational exposure to heavy metals: DNA damage induction and DNA repair inhibition prove co-exposures to cadmium, cobalt and lead as more dangerous than hitherto expected. Carcinogenesis. 2003; 24(1): 63-73.

6. Fojtová M., Kovařík A. Genotoxic effect of cadmium is associated with apoptotic changes in tobacco cells. Plant Cell Environ. 2000; 23(5): 531-537.

7. ABMS, 1994. Non-ferrous metal data, cadmium. American Bureau of Metal Statistic Inc. Secaucus, New Jersey.

8. Mirsalis JC, Butterworth BE. Detection of unscheduled DNA synthesis in hepatocytes isolated from rats treated with genotoxic agents: an in vivo - in vitro assay for potential carcinogens and mutagens. Carcinogenesis. 1980; 1(7): 621-625.

9. Muntau H, Baudo R. Sources of cadmium, its distribution and turnover in the freshwater environment. IARC Sci Publ. 1992; (118): 133148.

10. Nair AR, Degheselle O, Smeets K, Van Kerkhove E, Cuypers A. Cadmium-Induced Pathologies: Where Is the Oxidative Balance Lost (or Not)? Int J Mol Sci. 2013; 14(3): 61166143.

11. Thornton I. Sources and pathways of cadmium in the environment. IARC Sci. Publ. 1992; 118: 149-162.

12. Llewellyn TO. Cadmium. Minerals Yearbook. Bureau of mines. U.S. Department of the Interior. 1988; 1: 191-195.
13. EPA, 1988. Health effects assessment for cadmium. Cincinnati: OH. U. S. Environmental Protection Agency, Environmental Criteria and Assessment Office. EPA/600/8-89/087. NTIS no. PB90 - 142399.

14. Cadmium and certain cadmium compounds. In: IARC monographs of the evaluation of carcinogenic risk of chemicals to humans. Beryllium, cadmium, mercury and exposure in the glass manufactory industry. IARC monographs. 1993; 58. P. 119-146, 210-236.

15. Cadmium and certain cadmium compounds. In: Seventh Annual Report on Cancirogens, Summary 1991. U. S. National Toxicology Program. U. S. Public Health Service, Department of Health and Human Services. P. 114-121.

16. Kundiev YuI, Trakhtenberg IM. Chemical safety in Ukraine. Kiev: Avicenna, 2007. 72 p.

17. Toxicological Profile for Cadmium (Draft for Public Comment. Comment Periods Ends: February 17, 1998), U. S. Department of Health and Human Services. Public Health Service. Agency for toxic substances and disease registry. September 1997. 347 p.

18. Trakhtenberg IM, Tychinin VA, Talakin YuI. On the problem of carrier of heavy metals. Zhurn Akad Med Nauk Ukraine. 1999; 5(1): 87-95.

19. Waalkes MP, Oberdorster G. Cadmium Carcinogenesis. Foulkes E. C., ed. Metal carcinogenesis. Bosa Raton: CRC Press, 1990.

20. Waalkes MP, Wahba ZZ, Rodrigues RE. Cadmium. Hazardous Materials Toxicology. Clinical Principles of Environmental Health. Eds. J. B. Sullivan, G. R. Krieger. Williams and Wilkins. 1992, P. 845-852.

21. Stowe HD, Wilson M, Goyer RA. Clinical and morphologic effects of oral cadmium toxicity in rabbits. Arch Pathol. 1972; 94(5): 389-405.

22. Cárdenas A, Bernard A, Lauwerys R. Incorporation of $\left[{ }^{35}\right.$ S $]$ sulfate into glomerular membranes of rats chronically exposed to cadmium and its relation with urinary glycosaminoglycans and proteinuria. Toxicology. 1992; 76(3): 219-231.

23. Cárdenas A, Ramis I, Hotter G, Roselló J, Gelpí E, Roels H, Bernard A, Lauwerys R. Human and experimental studies on renal eicosanoid response to long-term cadmium exposure. Toxicol Appl Pharmacol. 1992; 116(2): 155-160. 
24. Roels H, Bernard AM, Cárdenas A, Buchet JP, Lauwerys RR, Hotter G, Ramis I, Mutti A, Franchini I, Bundschuh I. Markers of early renal changes induced by industrial pollutants. III. Application to workers exposed to cadmium. $\mathrm{Br} J$ Ind Med. 1993; 50(1): 37-48.

25. Friberg L. Health hazards in the manufacture of alkaline accumulators with special reference to chronic cadmium poisoning; a clinical and experimental study. Acta Med Scand Suppl. 1950; 240: 1-124.

26. Bonnell JA. Emphysema and proteinuria in men casting copper-cadmium alloys. $\mathrm{Br} J$ Ind Med. 1955; 12(3): 181-195.

27. Adams RG, Harrison JF, Scott P. The development of cadmium-induced proteinuria, impaired renal function, and osteomalacia in alkaline battery workers. Q J Med. 1969; 38(152): 425443.

28. Glaser U, Klöppel H, Hochrainer D. Bioavailability indicators of inhaled cadmium compounds. Ecotoxicol Environ Saf. 1986; 11(3): 261-271.

29. Oldiges $H$, Glaser U. The inhalative toxicity of different cadmium compounds in rats. Trace Elem Med. 1986; 3: 72-75.

30. Kutzman RS, Drew RT, Shiotsuka RN, Cockrell BY. Pulmonary changes resulting from subchronic exposure to cadmium chloride aerosol. J Toxicol Environ Health. 1986; 17(23):175-89.

31. Gill KD, Pal R, Nath R. Effect of cadmium on lipid peroxidation and antioxidant enzymes in undernourished weanling rat brain. Pharmacol Toxicol. 1989; 65(1): 73-77.

32. Gill KD, Pal R, Sandhir R. Effect of chronic cadmium exposure on lipid composition and peroxidation in liver and kidneys in rats. Med Sci Res. 1989; 17: 921-924.

33. Jamall IS, Smith JC. Effects of cadmium on glutathione peroxidase, superoxide dismutase, and lipid peroxidation in the rat heart: a possible mechanism of cadmium cardiotoxicity. Toxicol Appl Pharmacol. 1985; 80(1): 33-42.

34. Liu J, Qu W, Kadiiska MB. Role of oxidative stress in cadmium toxicity and carcinogenesis. Toxicol Appl Pharmacol. 2009; 238(3): 209-214.

35. Gubsky YuI, Levitsky EL, Lenchevskaia LK, Vistunova IE. Effect of cadmium chloride on DNA-, RNA-polymerase activity and lipid peroxidation of chromatin fraction in rat liver. Ukr Biokhim Zhurn. 1993; 65(5): 112-115. (In Russian).
36. Gubsky YuI. Cell death: free radicals, necrosis, apoptosis. Vinnytsia, 2015. 360 p.

37. Gobe G, Crane D. Mitochondria, reactive oxygen species and cadmium toxicity in the kidney. Toxicol Lett. 2010; 198(1): 49-55.

38. Minchenko OH, Tsymbal DO, Minchenko DO, Ratushna OO. The role of the TNF receptors and apoptosis inducing ligands in tumor growth. Ukr Biochem J. 2016; 88(5): 18-37.

39. Kitamura M, Hiramatsu N. The oxidative stress: endoplasmic reticulum stress axis in cadmium toxicity. Biometals. 2010; 23(5): 941-950.

40. Gubsky YuI, Levitsky EL. Peroxide-antioxidant mechanism of regulation of chromatin activity. Zhurn Akad Med Nauk Ukraine. 1997; 3(2): 275281.

41. Gubsky YuI, Levitsky EL. Mechanisms of the lipid peroxidation of the liver rats chromatin fractions. Biopolym Cell. 1993; 9(5): 34-43.

42. Levitsky EL, Gubsky YuI. Free radical damage of the nuclear genetic apparatus of cells. $U k r$ Biokhim Zhurn. 1994; 66(4): 18-30. (In Russian).

43. Gubsky YuI, Levitsky EL, Volkov GL. Fatty acid composition of rat liver chromatin fractions under conditions of stimulation of lipid peroxidation. Ukr Biokhim Zhurn. 1991; 63(1): 87-91. (In Russian).

44. Gubsky YuI, Levitsky EL, Primak RG, Golubov MI, Novikova SN. Conformational characteristics and packing of endogenous lipid fractions of transcriptionally active and repressed chromatin. Ukr Biokhim Zhurn. 1991; 63(2): 83-89. (In Russian).

45. Morselt AF, Leene W, De Groot C, Kipp JB, Evers M, Roelofsen AM, Bosch KS. Differences in immunological susceptibility to cadmium toxicity between two rat strains as demonstrated with cell biological methods. Effect of cadmium on DNA synthesis of thymus lymphocytes. Toxicology. 1988; 48(2): 127-139.

46. Gubskii YuI, Levitskii EL, Gol'dshtein NB, Litoshenko AYa. Lipid peroxidation and the endogenous DNA polymerase activity of fractions of isolated liver chromatin in rats. Biull Eksp Biol Med. 1989; 107(3): 296-298. (In Russian).

47. Meena Bai M, Divya K, Haseena Bhanu SK, Sailaja G, Sandhya D, Thyagaraju K. Evaluation of Genotoxic and Lipid Peroxidation Effect of Cadmium in Developing Chick Embryos. J Environ Anal Toxicol. 2014; 4(6): 238. 
48. Azza A. Ashmawy, Mohammed A. Rashed, Aiman H. Atta, Amr G. Ibrahim, Fagr Kh. Abdel-Gawad. Genotoxic Effect of Cadmium on Nile Tilapia (Oreochromis niloticus). Int J Sci Eng Res. 2015; 6(8): 971-978.

49. Sarkar A, Bhagat J, Ingole BS, Rao DP, Markad VL. Genotoxicity of cadmium chloride in the marine gastropod Nerita chamaeleon using comet assay and alkaline unwinding assay. Environ Toxicol. 2015; 30(2): 177-187.

50. Schwerdtle T, Ebert F, Thuy C, Richter C, Mullenders LH, Hartwig A. Genotoxicity of soluble and particulate cadmium compounds: impact on oxidative DNA damage and nucleotide excision repair. Chem Res Toxicol. 2010; 23(2): 432-442.

51. Jindal R, Verma S. In vivo genotoxicity and cytotoxicity assessment of cadmium chloride in peripheral erythrocytes of Labeo rohita (Hamilton). Ecotoxicol Environ Saf. 2015; 118: 1-10.

52. Hartmann A, Elhajouji A, Kiskinis E, Poetter F, Martus H, Fjällman A, Frieauff W, Suter W. Use of the alkaline comet assay for industrial genotoxicity screening: comparative investigation with the micronucleus test. Food Chem Toxicol. 2001; 39(8): 843-858.

53. Filipic M, Fatur T, Vudrag M. Molecular mechanisms of cadmium induced mutagenicity. Hum Exp Toxicol. 2006; 25(2): 67-77.

54. Gosslau A, Rensing L. Oxidative stress, age-dependent [correction of age-related] cell damage and antioxidative mechanisms. Z Gerontol Geriatr. 2002; 35(2): 139-150.

55. Arroyo VS, Flores KM, Ortiz LB, GómezQuiroz LE, Gutiérrez-Ruiz MC. Liver and Cadmium Toxicity. J Drug Metab Toxicol. 2012; S5: 001.

56. Hu KH, Li WX, Sun MY, Zhang SB, Fan CX, Wu Q, Zhu W, Xu X. Cadmium Induced Apoptosis in MG63 Cells by Increasing ROS, Activation of p38 MAPK and Inhibition of ERK 1/2 Pathways. Cell Physiol Biochem. 2015; 36(2): 642-654.

57. Rani A, Kumar A, Lal A, Pant M. Cellular mechanisms of cadmium-induced toxicity: a review. Int J Environ Health Res. 2014; 24(4): 378-399.
58. Madejczyk MS, Baer CE, Dennis WE, Minarchick VC, Leonard SS, Jackson DA, Stallings JD, Lewis JA. Temporal changes in rat liver gene expression after acute cadmium and chromium exposure. PLoS One. 2015; 10(5): e0127327.

59. Zhou ZH, Lei YX, Wang CX. Analysis of aberrant methylation in DNA repair genes during malignant transformation of human bronchial epithelial cells induced by cadmium. Toxicol Sci. 2012; 125(2): 412-417.

60. Fernández EL, Gustafson AL, Andersson M, Hellman B, Dencker L. Cadmium-induced changes in apoptotic gene expression levels and DNA damage in mouse embryos are blocked by zinc. Toxicol Sci. 2003; 76(1): 162-170.

61. Skipper A, Sims JN, Yedjou CG, Tchounwou PB. Cadmium chloride induces DNA damage and apoptosis of human liver carcinoma cells via oxidative stress. Int J Environ Res Public Health. 2016; 13(1). pii: E88.

62. Nemmiche S, Chabane-Sari D, Kadri M, Guiraud P. Cadmium chloride-induced oxidative stress and DNA damage in the human Jurkat $\mathrm{T}$ cell line is not linked to intracellular trace elements depletion. Toxicol In Vitro. 2011; 25(1): 191-198.

63. Mallya R, Chatterjee PK, Vinodini NA, Chatterjee P, Mithra P. Moringa oleifera leaf extract: beneficial effects on cadmium induced toxicities - a review. J Clin Diagn Res. 2017; 11(4): CE01-CE04.

64. Błasiak J. DNA-damaging effect of cadmium and protective action of quercetin. Pol $J$ Environ Stud. 2001; 10(6): 437-442.

65. Park JY, Seo YR. The protective role of Nrf2 in cadmium-induced DNA damage. Mol Cell Toxicol. 2011; 7(1): 61-66.

66. Cooke MS, Evans MD, Dizdaroglu M, Lunec J. Oxidative DNA damage: mechanisms, mutation, and disease. FASEB J. 2003; 17(10): 1195-1214.

67. Bertin G, Averbeck D. Cadmium: cellular effects, modifications of biomolecules, modulation of DNA repair and genotoxic consequences (a review). Biochimie. 2006; 88(11): 1549-1559.

Received 30.06.2017 